\title{
Environmental Awareness and Emotional Maturity: A Study on Secondary School Students
}

\author{
Tanveer Ahmad Bhat ${ }^{1}$, Prof. Ahrar Husain ${ }^{2}$, Mukhtar Ahmad Wani ${ }^{3}$
}

\section{ABSTRACT}

At present the world is witnessing numerous environmental problems, which are the result of unmindful exploitations of natural resources by human beings. There is an urgent need to create environmental awareness among all the citizens in general and student community in particular. The present study was conducted to study the relationship between Environmental Awareness and Emotional Maturity among Secondary School Students in district Anantnag of Jammu and Kashmir on a sample of randomly selected 250 students. The researchers found that there is significant correlation in Environmental Awareness and Emotional Maturity among Secondary School Students.

Keywords: Environmental Awareness, Emotional Maturity.

The environment comprises of physical, psychological, social and cultural aspects. Man being the crown of creation; whenever he tries to fulfill his need nature is at his disposal but for fulfilling his greed it depletes the nature to a larger extent which is not only harmful at present but it has its adverse effect on future generations as well. Optimal and judicious use of natural resources is not only best for the present generation but for the future as well. Environmental Awareness is an attitude towards the environment which manifests itself in terms of the awareness towards: physical pollution, psychological pollution, social pollution and cultural pollution.

National Environmental Awareness Campaign (NEAC) 2000-2001 the main aim of this campaign is to create Environmental Awareness at all the levels of the society. The main theme of the campaign is 'Keep our Environment Clean and Green'. In 2001 The Ministry of Environment and Forest interacted with University Grants Commission (UGC), National Council

\footnotetext{
${ }^{1}$ Research Scholar, Department of Teacher Training \& Non-formal Education, Jamia Millia Islamia, India

${ }^{2}$ Professor, Department of Teacher Training \& Non-formal Education, Jamia Millia Islamia, India

${ }^{3}$ Research Scholar Department of Educational Studies, Jamia Millia Islamia, India

*Responding Author

(C) 2016, T Bhat, A Husain, M Wani; licensee IJIP. This is an Open Access Research distributed under the terms of the Creative Commons Attribution License (http://creativecommons.org/licenses/by/2.0), which permits unrestricted use, distribution, and reproduction in any Medium, provided the original work is properly cited.
} 


\section{Environmental Awareness and Emotional Maturity: A Study on Secondary School Students}

for Education, Research and Training (NCERT) and Ministry of Human Resource Development (MHRD) for introducing environmental issues, themes and concepts etc. in the curriculum at all the levels of education i.e. from primary to higher education. Students can imbibe the values of their environment by proper utilization of social institutions especially family and the educational institutions. For keeping our environment clean and green The Government of India launched another campaign on $2^{\text {nd }}$ October 2014, the day commemorated as Gandhi jayanti under the name Swachh Bharat Abhiyaan.

The $21^{\text {st }}$ century is an era of technological revolution due to which the environment is changing as never before. Youth as well as adults of today are well and easily exposed to vast, unlimited and most importantly censored information and are subject to high pressure because of ever increasing competition and expectations from their family and peers. Under this dynamic environment the youth as well as adults are finding it difficult to adjust and even sometimes succumb to the environmental pressure. Though man has conquered time and space to a great extent by the present level of scientific advancement, yet there is great threat to his existence. The Indian society is becoming increasingly materialistic. The present generation is moving ahead to achieve material gains by every means. They find it hard to bridge the gap between their head and heart. This puts them always in conflicting situations. For the personal happiness it is very important that you must be aware about yourself and must be able to tolerate a delay in the satisfaction of your needs. For this purpose you have to choose maturity, to behave in a consciously designed manner. Maturity is the ability to respond to the environment in an appropriate manner. This response is generally learned rather than instinctive. Maturity also encompasses being aware of the correct time and place to behave and knowing when to act, according to the circumstances and the culture of the society one lives in (David Wechsler 1950). According to Finley (1996), "Maturity is the capacity of mind to endure an ability of an individual to respond to uncertainty, circumstances or environment in an appropriate manner".

As we discussed above that youths and adults are facing a lot of difficulties and pressures from the competitive materialistic world, so they are vulnerable to different psychological problems. Therefore, here the study of maturity in emotional aspect of personality is challenging our attention. Menninger (1999) "Emotional Maturity includes the ability to deal constructively with reality". Dosanjh (1960) "Emotional maturity means balanced personality" It means ability to govern disturbing emotion, show steadiness and endurance under pressure and be tolerant and free from neurotic tendency". Prof Y. Singh (1990) "Emotional maturity is not only the effective determinant of personality pattern but also helps to control the growth of an adolescent's development. A person who is able to keep his emotions under control, to brook delay and to suffer without self-pity might still be emotionally stunned". So emotionally mature person will have more satisfaction in life; he will be satisfied with what he is and have a balance between his head and heart. The investigators undertook the study to find out the significance between Environmental Awareness and Emotional Maturity in a turmoil hit region of the country. This 


\section{Environmental Awareness and Emotional Maturity: A Study on Secondary School Students}

was a humble attempt by the researchers in this direction which will prove fruitful for future researchers.

\section{Objectives:}

1.To study the relationship between Environmental Awareness and Emotional Maturity among Secondary School Students.

2.To study differences between Rural and Urban Secondary School Students on Environmental Awareness and Emotional Maturity.

3.To study the difference between Government and Private Secondary School Students on Environmental Awareness and Emotional Maturity.

4.To study the difference on Environmental Awareness and Emotional Maturity across gender.

\section{Hypothesis}

1. There is no significant relationship between Environmental Awareness and Emotional Maturity among Secondary School Students.

2. There is no significant relationship between Rural and Urban Secondary School Students on Environmental Awareness and Emotional Maturity.

3. There is no significant relationship between Government and Private Secondary School Students on Environmental Awareness and Emotional Maturity.

\section{Design}

The present study was carried out by employing the co relational design

\section{Sample}

The participants for the present investigation were randomly drawn from different Secondary Schools of district Anantnag, Jammu and Kashmir. A total number of 250 Secondary School students from rural and urban Secondary Schools.

\section{Tool}

- Environmental Awareness Ability Measure developed by Dr. Praveen Kumar Jha (1998).

- Emotional Maturity Scale developed by Prof. Yeshver Singh \& Prof. Mahesh Bhargave (1990).

\section{Procedure}

Before the administration of the test, the nature of the data and the purpose of researchers were discussed with the sample population. Then the test was administered. After the administration of the test to the selected sample, the scoring was done strictly in accordance with the directions in the test manuals. The collected data was statistically analyzed through mean, standard deviation and t-test for testing the significance of mean differences between the groups with the help of SPSS 21 Software. The details of analysis and interpretation are given below: 
Environmental Awareness and Emotional Maturity: A Study on Secondary School Students

Table: Bivariate correlation between Environmental awareness and Emotional maturity

\begin{tabular}{|c|c|}
\hline Environmental Awareness & Correlation (r) \\
\hline Emotional Maturity & $-.27^{* *}$ \\
\hline \multicolumn{2}{|c|}{ Significant at .01 }
\end{tabular}

The above table 1 represents the correlation between environmental awareness and emotional maturity of secondary school students. It is revealed that environmental awareness has a negative significant correlation with emotional maturity, $r(248)=-.27 ; p<.01$. This indicates that, as the emotional maturity (Higher the score on emotional maturity scale indicates the higher emotional immaturity and vice-versa) scores increases there is decrease in the environmental awareness and lower the emotional immaturity and higher will be the environmental awareness among secondary school students. Therefore the null hypothesis stating that 'there is no significant relationship between Environmental Awareness and Emotional Maturity among Secondary School Students" is rejected.

Table: Mean score comparison on Environmental Awareness and Emotional Maturity across demographic variables

\begin{tabular}{|c|c|c|c|c|c|c|}
\hline Variable & Group & $\mathbf{N}$ & $\mathbf{M}$ & Std. D & t & Sig. \\
\hline \multirow{6}{*}{$\begin{array}{c}\text { Environmental } \\
\text { Awareness }\end{array}$} & Rural & 141 & 19.97 & 9.05 & \multirow[t]{2}{*}{2.19} & \multirow[t]{2}{*}{0.029} \\
\hline & Urban & 109 & 17.74 & 8.77 & & \\
\hline & Male & 137 & 19.06 & 9.54 & \multirow[t]{2}{*}{-0.486} & \multirow[t]{2}{*}{0.627} \\
\hline & Female & 113 & 19.62 & 8.55 & & \\
\hline & Govt. & 142 & 19.60 & 9.65 & \multirow[t]{2}{*}{1.90} & \multirow[t]{2}{*}{0.049} \\
\hline & Private & 108 & 17.46 & 7.53 & & \\
\hline \multirow{6}{*}{$\begin{array}{c}\text { Emotional } \\
\text { Maturity }\end{array}$} & Rural & 141 & 89.20 & 12.72 & \multirow[t]{2}{*}{-5.62} & \multirow[t]{2}{*}{$0.00^{\text {** }}$} \\
\hline & Urban & 109 & 99.20 & 14.83 & & \\
\hline & Male & 137 & 94.44 & 15.57 & \multirow[t]{2}{*}{3.80} & \multirow[t]{2}{*}{$0.00^{* *}$} \\
\hline & Female & 113 & 87.84 & 10.90 & & \\
\hline & Govt. & 142 & 93.06 & 14.18 & \multirow[t]{2}{*}{-0.546} & \multirow[t]{2}{*}{0.586} \\
\hline & Private & 108 & 94.02 & 13.53 & & \\
\hline
\end{tabular}

${ }^{* *}$ Significant at 0.01

* Significant at 0.05

The above table represents the mean score comparison on environmental awareness and emotional maturity across some demographic variables. It was found that there is a significant difference between rural and urban secondary school students on environmental awareness, $t$ $(248)=2.19 ; p<.05$. On a two point scale, rural averaged 19.97 (SD = 9.05) and urban students averaged 17.47 (SD = 8.77). It reveals that rural students have high environmental awareness than urban. In case of gender, no significant difference was found on environmental awareness, $t$ $(248)=-.486 ; p>.05$. On a two point scale, boys averaged 19.06 (SD = 9.54) and girl students averaged 19.62 (SD = 8.55). On government and private secondary school comparison on

(C) The International Journal of Indian Psychology, ISSN 2348-5396 (e)| ISSN: 2349-3429 (p) | 45 


\section{Environmental Awareness and Emotional Maturity: A Study on Secondary School Students}

environmental awareness, a significant difference was found, $t(248)=1.90 ; p<.05$. On a two point scale, government averaged $19.60(\mathrm{SD}=9.65)$ and urban students averaged $17.46(\mathrm{SD}=$ 7.53). It reveals that rural students have high environmental awareness than urban .It reveals that government secondary school students have high environmental awareness than private secondary school students.

In case of rural urban comparison on emotional maturity among secondary school students, a significant difference was found, $t(248)=-5.62 ; p<.01$. On a five point scale, rural .averaged 89.20 ( $\mathrm{SD}=12.72$ ) and urban students averaged 99.02 ( $\mathrm{SD}=14.83$ ). It reveals that urban secondary school students scored higher than rural which indicates that rural secondary school students are emotionally mature than their urban counterparts (higher the score on emotional maturity scale, lesser the emotional maturity and vice-versa). In case of gender, a significant difference was found between boy and girl secondary school students on emotional maturity, $t$ $(248)=3.80 ; p<.01$. On a five point scale, boys averaged 94.44. (SD = 15.57) and girl students averaged $87.84(\mathrm{SD}=10.90)$. It reveals that boys secondary school students scored higher than girls which indicates that girls secondary school students are emotionally mature than their male counterparts (higher the score on emotional maturity scale, lesser the emotional maturity and vice-versa). On government and private secondary school comparison on emotional maturity, a significant difference was found, $t(248)=-.546 ; p>$.05. On a five point scale, government averaged $93.06(\mathrm{SD}=14.18)$ and private secondary school students averaged $94.02(\mathrm{SD}=$ 13.53). It reveals that there is no significant difference between government and private secondary school students on emotional maturity.

\section{FINDINGS AND DISCUSSION}

Findings revealed that there is a significant negative correlation between environmental awareness and emotional maturity of secondary school students. This indicates that, as the emotional maturity scores (higher the score on emotional maturity scale indicates the higher emotional immaturity and vice-versa) increases there is decrease in the environmental awareness and lower the emotional immaturity and higher will be the environmental awareness among secondary school students. Therefore the null hypothesis stating that 'there is no significant relationship between Environmental Awareness and Emotional Maturity among Secondary School Students" is rejected.

Further, the study reveals that the rural secondary school students have more environmental awareness than the urban. Gender does not play any part in environmental awareness .Government secondary school students scored higher than their private counterparts on environmental awareness. On the other hand, the rural secondary school students are emotionally more mature than the urban. On the basis of gender; girls are found to be more mature than the boys. No significant difference was found between private and government secondary school students on emotional maturity. 


\section{Environmental Awareness and Emotional Maturity: A Study on Secondary School Students}

The study reveals that the emotional maturity and environmental awareness are significantly related i.e. higher the emotional maturity of an individual higher is his environmental awareness.

\section{CONCLUSION}

The present study highlights that the adolescents enrolled at secondary level are passing through the critical period of their lives; on one hand they undergo many physiological changes and on the other they are experiencing many social issues which seem to be new and challenging to them. All the social institutions - family, school, clubs, religion, polity etc. have to perform their roles as per their structure and keeping in view the all round development of the child. Most of the studies conducted on emotional maturity reveal that the children of well adjusted families are emotionally mature than the children of maladjusted families. After family environment the child experiences the school environment. Congenial atmosphere at school plays a major role for a child to be emotionally mature; the other social institutions are almost all equally responsible for

a child to be emotionally mature. From the finds it is evident that there is significant relationship between emotional maturity and environmental awareness among the secondary school students. So, an individual can be sensitized well regarding the environment when he is emotionally mature.

\section{EDUCATIONAL IMPLICATIONS}

The present study may help the parents, teachers and administrators to have knowledge of the emotional development of their children and students and help them in building a well balanced personality. Emotional Development is one of the major aspects of human growth and development. Emotions like anger, fear, love etc. play a great role in the development of child's personality. Not only his physical growth and development is linked with his emotional makeup, but his intellectual, social, moral and aesthetic development are also controlled by his emotional behavior and experiences. The overall importance of emotional experiences in the life of a human being makes it quite essential to know about the emotions. Emotional development reaches its maximum in adulthood. During this stage, generally all individuals attain emotional maturity. An individual can be sensitized well in every walk of life provided he is emotionally Mature. To sensitize the students regarding the physical environment emotional maturity plays a vital role.

Emotionally mature students are able to safeguard their their Environment as they are physically as well as intellectually sound. They need only a direction to chanalise their potential for the welfare of the society as they are free from any stress and strain.In this way, Emotional Maturity can render yeoman's service for making the individuals Environmentally Awareness.

\section{Acknowledgments}

The author appreciates all those who participated in the study and helped to facilitate the research process. 


\section{Environmental Awareness and Emotional Maturity: A Study on Secondary School Students}

\section{Conflict of Interests}

The author declared no conflict of interests.

\section{REFERENCES}

Abraham \& Nair, C. (1998). Attitude of secondary school students towards environmental protection: Differential effect of gender and locale. Pedagogies. 1(1):2731.

Ferguson, G. A., \& Yashio, T. (1989). Statistical Analysis in Psychology and Education. New York: McGraw Hill Book Co.

Hangal, S., \& Aminabhavi, A. (2007).Self- Concept, Emotional Maturity and Achievement Motivation of the Adolescent Children of Employed Mothers and Homemakers. Journal of Indian Academy of Applied Psychology, 33(1), 103-110

Garret, H. E. (1973). Statistics in Psychology and Education. New Delhi: Paragon International Publishers.

Jaiprakash \& G.B. Narain. (2001). Environmental education for sustainable development. Indian Education Review, vol. 37, pp. 20-23

Kaur, M. M. (2013, january). A Comparative study of Emotional Maturity of Senior Secondary School Students. International Indexed Referred Reseach Journal, 48-49.

Praveen Kumar Jha (1998). Manual for Environment Awareness Ability Measure, Agra, India: National Psychological Corporation.

Passer, M. M., \& Smith, R. E. (2009). Psychology: The Science of Mind and Behavior (4th ed.). New York: McGraw-Hill Companies, Inc.

Stapp, W.B., et al. (1969). The Concept of Environmental Education," The Journal of Environmental Education.vol 1(1) pp: 30-31

Wani, M. A., \& Masih, A. (2015). Emotional Maturity across gender and level of education. The International Journal of Indian Psychology, 2(2), 63-72.

How to cite this article: T Bhat, A Husain, M Wani (2016), Environmental Awareness and Emotional Maturity: A Study on Secondary School Students, International Journal of Indian Psychology, Volume 3, Issue 4, No. 64, ISSN 2348-5396 (e), ISSN: 2349-3429 (p), DIP:18.01.120/20160304, ISBN: 978-1-365-32519-9 